\title{
Sample Preparation Using TMAH and Nitric Acid for Multielement Determination in Crustacean Samples by MIP OES
}

\author{
Michelle S. Lemos, ${ }^{\oplus a}$ Allan S. Cruz ${ }^{\oplus a}$ and Kelly G. F. Dantas ${ }^{(*, a}$ \\ ${ }^{a}$ Grupo de Espectrometria Analítica Aplicada, Faculdade de Química, \\ Universidade Federal do Pará, Rua Augusto Corrêa, 01, 66075-110 Belém-PA, Brazil
}

\begin{abstract}
This study proposes a simple sample preparation procedure using tetramethylammonium hydroxide (TMAH) and nitric acid $\left(\mathrm{HNO}_{3}\right)$ to determine $\mathrm{Cr}, \mathrm{Cu}, \mathrm{Fe}, \mathrm{K}, \mathrm{Mg}, \mathrm{Mn}$, and $\mathrm{Zn}$ concentrations in shrimp (Macrobrachium amazonicum) and crab (Ucides cordatus) samples from the Amazon region by microwave-induced plasma optical emission spectrometry (MIP OES). The sample solubilization was carried out employing TMAH and $\mathrm{HNO}_{3}$ using an ultrasound bath and a thermostatic water bath. The accuracy of the proposed procedure was performed using microwaveassisted digestion as comparative method. Certified fish protein reference material (DORM-4) and also addition recovery experiments were used to assess the accuracy of the proposed procedure and recoveries obtained were adequate, ranging from 91 to $106 \%$. In this study, the use of TMAH and $\mathrm{HNO}_{3}$ simplified sample preparation, maintaining the identity of analytes and ensuring efficiency in determinations.
\end{abstract}

Keywords: tetramethylammonium hydroxide, shrimp, crab, microwave induced plasma, inorganic elements

\section{Introduction}

Crustaceans are highly appreciated animals worldwide due to their distinctive taste and nutritional characteristics, with high levels of protein, vitamins and minerals. ${ }^{1,2}$ Although balanced consumption of crustaceans is considered beneficial to human health, aiding in disease prevention and cholesterol control, ${ }^{3,4}$ high consumption of these animals may represent a health risk, since they have the capacity to accumulate contaminants and transfer them to the food chain. ${ }^{5}$

Some elements are considered essential, such as copper, iron and zinc, as they contribute to the maintenance of essential biological properties for living beings. However, when in excess, they can cause adverse effects, ranging from intestinal disorders to death. ${ }^{6,7}$ Therefore, studying the levels of inorganic constituents in crustaceans is important to evaluate the food safety of the consuming population.

It is known that sample preparation is a very critical step of chemical analysis and in recent years have been the subject of studies aiming, among other aspects, to reduce costs and time of analysis and the amount of waste generated. Given that most sample preparation procedures use acid digestion, studies involving alkaline solubilization

*e-mail: kdgfernandes@ufpa.br with tetramethylammonium hydroxide (TMAH) have been a viable alternative and have been successfully used for different matrices such as meat, biodiesel, cosmetics and fish..$^{8-11}$

TMAH is a strong organic base ( $\mathrm{pH}$ ranging from 13.4 to 14.7) derived from a quaternary ammonium salt that is stable at room temperature and soluble in water or alcohols. ${ }^{12}$ The use of small reagent volumes, shorter time, simpler sample preparation and lower risk of contamination are some of the advantages obtained from samples treated with TMAH. ${ }^{8,9}$

Most studies involving the use of TMAH in sample preparation are related only to its alkaline potential in the solubilization of different matrices using relatively fast procedures for elementary determination by atomic absorption spectrometry (AAS), graphite furnace atomic absorption spectrometry (GFAAS), inductively coupled plasma optical emission spectrometry (ICP OES) or inductively coupled plasma mass spectrometry (ICP-MS). ${ }^{13-17}$ However, no reports can be found regarding the determination of elements by microwave induced plasma optical emission spectrometry using nitrogen plasma and TMAH solubilization.

Microwave-induced plasma optical emission spectrometry (MIP OES) has become an attractive technique due to its simplicity of operation, low cost of analysis (nitrogen obtained from own generator) and multielementary capacity. ${ }^{6,18}$ However, the $\mathrm{N}_{2}$ plasma operates 
at relatively lower temperatures when compared to an argon plasma in an ICP, which may result in matrix effects and compromise the precision and accuracy of the results in complex matrices, especially for high carbon-content matrices. ${ }^{19,20}$ These effects can be eliminated or minimized through the use of internal standards, calibration strategies, adequate dilution, among others. ${ }^{20-22}$ MIP OES is currently being used in different matrices, such as fertilizers, ${ }^{23}$ diesel and biodiese $\mathrm{l}^{24}$ and in various types of foods. ${ }^{6,25,26}$

In this context, the purpose of this study was to apply a simple procedure for the preparation of shrimp (Macrobrachium amazonicum) and crab (Ucides cordatus) samples using TMAH and $\mathrm{HNO}_{3}$ to determine inorganic element concentrations by microwave induced plasma optical emission spectrometry (MIP OES) aiming at reducing the volume of reagents and generating less residue when compared to acid digestion procedures.

\section{Experimental}

\section{Samples}

Eleven crustacean samples were studied. Shrimp samples (pool of 20 individuals per sample) and crab samples (one individual per sample) were obtained from local fishermen in different municipalities (Barcarena, Monte Alegre, Abaetetuba, Soure, and São Caetano de Odivelas) of the state of Pará, Northern Brazil. After collection, samples were transported to the laboratory for further analysis.

Prior to analysis, all samples were previously washed with deionized water and the muscles of crustaceans were removed with stainless steel scissors and stored at $-16{ }^{\circ} \mathrm{C}$. The samples were lyophilized for $72 \mathrm{~h}$ and ground in a cryogenic mill. The pulverized samples were stored in clean flasks in a desiccator.

\section{Materials and reagents}

All reagents used were of analytical grade. Solutions were prepared with ultrapure water obtained from a
Sinergy-UV purification system (Millipore, Bedford, USA) with resistivity of $18.2 \mathrm{M} \Omega \mathrm{cm}$.

TMAH aqueous solution (25\% $\mathrm{m} \mathrm{v}^{-1}$ ) (Sigma-Aldrich, St. Louis, MO, USA) and $\mathrm{HNO}_{3}\left(65 \%, \mathrm{v} \mathrm{v}^{-1}\right)$ (Sigma-Aldrich, St. Louis, MO, USA) were used for sample preparation. Nitric acid used was previously purified in a sub-distillation system (Berghof, model BSP 929-IR, Eningen, Germany). Hydrogen peroxide $30 \%\left(\mathrm{~m} \mathrm{~m}^{-1}\right)$ (Impex, Diadema, SP, Brazil) was used in the digestion of the samples.

Instrumentation

A lyophilizer (model L101, Liotop, São Carlos, SP, Brazil) and a cryogenic mill (model 6770, SPEX SamplePrep, Metuchen, NJ, USA) were used to freeze-dry and grind the sample, respectively.

A microwave induced plasma optical emission spectrometer (MIPOES) (model 4100, Agilent Technologies, Melbourne, Australia) was used for determination of $\mathrm{Cr}$, $\mathrm{Cu}, \mathrm{Fe}, \mathrm{K}, \mathrm{Mg}, \mathrm{Mn}$, and $\mathrm{Zn}$ in samples. A concentric nebulizer and double pass glass cyclonic spray chamber (Agilent Technologies, Melbourne, Australia) were used during analysis. The MP Expert software optimized the plasma viewing position and the nebulizer pressure for each element studied. The instrumental conditions used are presented in Table 1. A Microprocessed Dubnoff bath (model Q226M2, Quimis, São Paulo) and Biowash STD ultrasound bath (model CD-4820, China) were used for the solubilization process of crustacean samples using TMAH and $\mathrm{HNO}_{3}$. Centrifuge (model Q222T2, Quimis, São Paulo, Brazil) was used to separate the waste resulting from the solubilization process.

In order to compare with the previous procedure, the acid digestion was performed in a microwave oven (Start E, Milestone, Sorisole, Italy).

TMAH and $\mathrm{HNO}_{3}$ solubilization

The sample preparation proposed using TMAH and $\mathrm{HNO}_{3}$ was based on procedure proposed by Szymczycha-

Table 1. Optimized operating conditions for elements determination by MIP OES

\begin{tabular}{|c|c|c|c|c|c|c|c|}
\hline Parameter & $\mathrm{Cr}$ & $\mathrm{Cu}$ & $\mathrm{Fe}$ & $\mathrm{K}$ & $\mathrm{Mg}$ & $\mathrm{Mn}$ & $\mathrm{Zn}$ \\
\hline Wavelength $^{\mathrm{a}} / \mathrm{nm}$ & 425.433 & 324.754 & 371.993 & 766.491 & 518.360 & 403.076 & 213.857 \\
\hline Nebulizer pressure / $\mathrm{kPa}$ & 240 & 240 & 240 & 240 & 240 & 240 & 140 \\
\hline Viewing position & 0 & 0 & -10 & 10 & 0 & 0 & 10 \\
\hline Background correction & auto & auto & auto & auto & auto & auto & auto \\
\hline Sample uptake delay / s & 15 & 15 & 15 & 15 & 15 & 15 & 15 \\
\hline Stabilization time / s & 15 & 15 & 15 & 15 & 15 & 15 & 15 \\
\hline
\end{tabular}

${ }^{\mathrm{a} A t o m i c ~ l i n e s . ~}$ 
Madeja $\mathrm{a}^{27}$ with adaptations. Approximately $0.25 \mathrm{~g}$ of each crustacean sample were weighed in polyethylene flask $(\mathrm{n}=3)$, and then $1.0 \mathrm{~mL}$ of a $25 \% \mathrm{~m} \mathrm{v}^{-1}$ TMAH aqueous solution was added. Samples were sonicated in ultrasound bath for $30 \mathrm{~min}$. Then, $1.0 \mathrm{~mL}$ of $14 \mathrm{~mol} \mathrm{~L}^{-1} \mathrm{HNO}_{3}$ was added to each flask and taken to thermostatic water bath at $70{ }^{\circ} \mathrm{C}$ for $10 \mathrm{~min}$ at $250 \mathrm{rpm}$. After cooled to room temperature, the solutions obtained were diluted to $25 \mathrm{~mL}$ with ultrapure water. To avoid residue deposition during analysis, the solutions were centrifuged and filtered. Analytical blanks were prepared by the same procedure without sample addition. The determinations of $\mathrm{Cr}, \mathrm{Cu}$, $\mathrm{Fe}, \mathrm{K}, \mathrm{Mg}, \mathrm{Mn}$, and $\mathrm{Zn}$ in solutions were performed by MIP OES.

\section{Microwave-assisted digestion}

In order to check the accuracy of the procedure of sample preparation proposed, a crustacean sample (S4) was submitted to acid digestion in a microwave oven with cavity using nitric acid and hydrogen peroxide as described by Lemos et al. ${ }^{6} \mathrm{~A}$ volume of $4 \mathrm{~mL}$ of $\mathrm{HNO}_{3}\left(14 \mathrm{~mol} \mathrm{~L}^{-1}\right)$, $4 \mathrm{~mL}$ of $30 \%\left(\mathrm{~m} \mathrm{~m}^{-1}\right) \mathrm{H}_{2} \mathrm{O}_{2}$ and $4 \mathrm{~mL}$ of $\mathrm{H}_{2} \mathrm{O}$ were added to $0.25 \mathrm{~g}$ of crustacean sample. The microwave heating program consisted of three steps: $800 \mathrm{~W}, 180^{\circ} \mathrm{C}$ for $10 \mathrm{~min}$ (ramp); $800 \mathrm{~W}, 180^{\circ} \mathrm{C}$ for $20 \mathrm{~min}$ (hold) and ventilation for $50 \mathrm{~min}$. After cooling, the digests were transferred to volumetric flasks and the volume was set to $20 \mathrm{~mL}$ with ultrapure water. The elements were determined by MIP OES.

\section{Accuracy}

The accuracy of the measurements by MIP OES was verified using certified reference material of fish protein (DORM-4) and also by the method of recovery addition. The solutions obtained after TMAH and $\mathrm{HNO}_{3}$ solubilization were spiked with different concentrations of
$\mathrm{Cr}\left(0.5,1.0\right.$ and $\left.1.5 \mathrm{mg} \mathrm{L}^{-1}\right), \mathrm{Cu}, \mathrm{Fe}, \mathrm{Mn}$, and $\mathrm{Zn}(5.0,10.0$ and $\left.15.0 \mathrm{mg} \mathrm{L}^{-1}\right)$ and $\mathrm{K}$ and $\mathrm{Mg}\left(10.0,20.0\right.$ and $\left.30.0 \mathrm{mg} \mathrm{L}^{-1}\right)$ and resulting solutions were analyzed by MIP OES.

Figures of merit

Limits of detection (LOD) and quantification (LOQ) were calculated using the following equations: $\mathrm{LOD}=0.03 \times \mathrm{RSD}_{\text {Blank }} \times \mathrm{C}_{\mathrm{SR}} /\left(\mathrm{I}_{\mathrm{SR}} / \mathrm{I}_{\text {Blank }}\right)$; $\mathrm{LOQ}=0.10 \times \mathrm{RSD}_{\text {Blank }} \times \mathrm{C}_{\mathrm{SR}} /\left(\mathrm{I}_{\mathrm{SR}} / \mathrm{I}_{\text {Blank }}\right)$, where RSD is the relative standard deviation of the analytical blank $(\mathrm{n}=10) ; \mathrm{C}_{\mathrm{SR}}$ represents the analyte concentration present in the multi-element reference solution; $\mathrm{I}_{\mathrm{SR}}$ and $\mathrm{I}_{\mathrm{Blank}}$ are the emission intensities of analytes in the reference solution and blank, respectively. ${ }^{28}$ The background equivalent concentration (BEC) and signal-to-background ratio (SBR) were calculated according to previous studies. ${ }^{29}$ Limit of detection (LOD), limit of quantification (LOQ), BEC and SBR are presented in Table 2.

\section{Results and Discussion}

\section{MIP OES optimization}

The selection of wavelengths was performed by choosing the free lines of spectral interferers for each element. In order to increase sensitivity and ensure the best analytical signal, nebulizer pressure $(\mathrm{kPa})$ and plasma display position $(\mathrm{mm})$ were automatically optimized by the MP Expert software, using an intermediate standard solution containing all analytes under study. The instrument software also performs automatic background correction by automatically subtracting a spectrum from the background signal obtained from the analytical blank of each reference solution and sample analyzed. Thus, optimizations made by the instrument allow each element to be analyzed in its best condition.

Table 2. Figures of merit for MIP OES

\begin{tabular}{|c|c|c|c|c|c|c|c|}
\hline Element & SBR & $\mathrm{BEC} /\left(\mathrm{mg} \mathrm{L}^{-1}\right)$ & $\mathrm{LOD} /\left(\mathrm{mg} \mathrm{kg}^{-1}\right)$ & $\mathrm{LOQ} /\left(\mathrm{mg} \mathrm{kg}^{-1}\right)$ & $\mathrm{RSD} / \%$ & $\mathrm{R}^{2}$ & $\begin{array}{c}\text { Calibration range / } \\
\left(\mathrm{mg} \mathrm{L}^{-1}\right)\end{array}$ \\
\hline $\mathrm{Cr}$ & 288.41 & 0.0017 & 0.07 & 0.22 & 14.0 & 0.995 & $0.25-1.5$ \\
\hline $\mathrm{Cu}$ & 2645.59 & 0.0038 & 0.14 & 0.46 & 12.5 & 0.999 & $5-20$ \\
\hline $\mathrm{Fe}$ & 133.02 & 0.0376 & 0.35 & 1.15 & 3.1 & 0.999 & $5-20$ \\
\hline K & 464.94 & 0.0860 & 0.86 & 2.86 & 3.3 & 0.999 & $10-50$ \\
\hline $\mathrm{Mg}$ & 680.11 & 0.0294 & 0.54 & 1.80 & 6.1 & 0.996 & $10-50$ \\
\hline $\mathrm{Mn}$ & 602.35 & 0.0083 & 0.40 & 1.33 & 16.1 & 0.999 & $5-20$ \\
\hline $\mathrm{Zn}$ & 1291.85 & 0.0039 & 0.15 & 0.50 & 13.0 & 0.998 & $5-20$ \\
\hline
\end{tabular}

SBR: signal-to-background ratio; BEC: background equivalent concentration; LOD: limit of detection; LOQ: limit of quantification; RSD: relative standard deviations; $\mathrm{R}^{2}$ : linear correlation coefficients. 
In this study, plasma air injection mechanisms were not used, which are generally used to prevent carbon deposition in the torch and optical components. ${ }^{30}$ However, no disadvantages were observed due to the absence of this component for the analytes studied, such as carbon deposition or wear on the torch. Adequate dilution may have contributed to controlling the effect of the matrix in the studied samples.

\section{Analytical performance}

Figures of merit are shown in Table 2. The LODs for Cr, $\mathrm{Cu}, \mathrm{Fe}, \mathrm{K}, \mathrm{Mg}, \mathrm{Mn}$, and $\mathrm{Zn}$ were $0.07,0.14,0.35,0.86,0.54$, 0.40 , and $0.15 \mathrm{mg} \mathrm{kg}^{-1}$, respectively. The LOD found for $\mathrm{Cu}$ in this study was the same value $\left(0.14 \mu \mathrm{g} \mathrm{g}^{-1}\right)$ obtained by Ribeiro et al. ${ }^{31}$ using coffee TMAH method and ICP OES. Limit of detection for Fe $\left(0.35 \mu \mathrm{g} \mathrm{g}^{-1}\right)$ was better when compared to other study found in the literature using TMAH and FAAS $\left(23.0 \mu \mathrm{g} \mathrm{g}^{-1}\right) .{ }^{13}$ Nunes et al. ${ }^{8}$ and Ribeiro et al. ${ }^{31}$ found higher LODs for Fe $\left(0.70 \mu \mathrm{g} \mathrm{g}^{-1} ; 0.50 \mu \mathrm{g} \mathrm{g}^{-1}\right)$ using TMAH and ICP OES. For K, the LOD found in the present study was approximately 119 -fold lower than those obtained by Ribeiro et al..$^{31} \mathrm{In}$ the case of Mg, higher LODs were found by Silva et al. ${ }^{13}\left(107.0 \mu \mathrm{g} \mathrm{g}^{-1}\right)$ and Ribeiro et $a l .{ }^{31}\left(1.3 \mu \mathrm{g} \mathrm{g}^{-1}\right)$ when compared to this study. On the other hand, Nunes et al. ${ }^{8}$ obtained for $\mathrm{Mg}$ a limit of detection 4.5fold lower than the value found in this study. The LOD for $\mathrm{Mn}$ in the present study was approximately 5.0- and 12.1fold higher than those found by Nunes et al. ${ }^{8}$ and Ribeiro et $a l .{ }^{31}$ In this study, the LOD for Zn was approximately 19.3- and 2.2- fold lower when compared with to the LOD values observed by Silva et al. ${ }^{13}$ using TMAH and FAAS $\left(2.9 \mu \mathrm{g} \mathrm{g}^{-1}\right)$ and Nunes et al. ${ }^{8}$ using TMAH and ICP OES $\left(0.33 \mu \mathrm{g} \mathrm{g}^{-1}\right)$. Ribeiro et al..$^{31}$ found a lower LOD for $\mathrm{Zn}\left(0.11 \mu \mathrm{g} \mathrm{g}^{-1}\right)$ using coffee TMAH method. The milk TMAH method described by Ribeiro et al. ${ }^{31}$ presented lower LODs (Fe, Mg, Mn, and $\mathrm{Zn}$ ) when compared to the LODs observed here. Matusiewicz and Golik ${ }^{32}$ found higher LODs for $\mathrm{Cu}\left(1.5 \mu \mathrm{g} \mathrm{g}^{-1}\right), \mathrm{Fe}\left(3.0 \mu \mathrm{g} \mathrm{g}^{-1}\right)$, $\mathrm{K}\left(560.0 \mu \mathrm{g} \mathrm{g}^{-1}\right), \mathrm{Mg}\left(2.5 \mu \mathrm{g} \mathrm{g}^{-1}\right)$, and $\mathrm{Zn}\left(1.4 \mu \mathrm{g} \mathrm{g}^{-1}\right)$ using Ar-MIP OES. The high limits of detection found by some authors reported in the literature ${ }^{12,31}$ can be to impurity in the TMAH reagent. In general, low limits of detection were obtained in this study when compared with the reported works here.

Analytical parameters were obtained by preparing the analytical curves in the same medium used for the sample preparation with TMAH and $\mathrm{HNO}_{3}$. Analytical curves presented good linear correlation coefficients $\left(R^{2}>0.995\right)$.

Regarding the relative standard deviations (RSD) obtained, which ranged from 3.1 (for $\mathrm{Fe}$ ) to $16.1 \%$ (for $\mathrm{Mn}$ ), indicating that the developed procedure was precise for all analytes, since the RSD values were less than $20 \%$.

The accuracy of the proposed procedure was performed using microwave-assisted digestion as a comparative method.

The values found for $\mathrm{Cr}, \mathrm{Cu}, \mathrm{Fe}, \mathrm{K}, \mathrm{Mg}, \mathrm{Mn}$, and $\mathrm{Zn}$ in crustacean sample by microwave-assisted acid digestion and solubilization with TMAH and $\mathrm{HNO}_{3}$ are shown in Table 3.

Considering the contents of the studied elements, it is possible to observe that the concentrations obtained for the procedure proposed in this study using TMAH and $\mathrm{HNO}_{3}$, leads to results close to the acid digestion procedure with a microwave oven. The paired $t$-test showed that there are no significant differences at $95 \%$ confidence between concentrations obtained for the two procedures. Thus, the solubilization of crustacean samples using TMAH and $\mathrm{HNO}_{3}$ can be used as an alternative procedure to the conventional acid digestion procedure.

The relative standard deviation (RSD) values for the TMAH and $\mathrm{HNO}_{3}$ procedure were higher than those observed in microwave-assisted acid digestion, in most cases. However, the RSD values were adequate for this

Table 3. Concentration of elements obtained in a sample of crustacean (S4) by MIP OES using different sample preparation procedures: microwave-assisted acid digestion and TMAH and $\mathrm{HNO}_{3}$ solubilization

\begin{tabular}{|c|c|c|c|c|c|c|}
\hline \multirow{2}{*}{ Element } & \multirow{2}{*}{$\lambda / \mathrm{nm}$} & \multicolumn{2}{|c|}{ Microwave acid digestion } & \multicolumn{2}{|c|}{ TMAH and $\mathrm{HNO}_{3}$} & \multirow{2}{*}{$t$-test value } \\
\hline & & Found / $\left(\mathrm{mg} \mathrm{kg}^{-1}\right)$ & $\mathrm{RSD} / \%$ & Found / $\left(\mathrm{mg} \mathrm{kg}^{-1}\right)$ & $\mathrm{RSD} / \%$ & \\
\hline $\mathrm{Cr}$ & 425.433 & $<$ LOD & - & $<$ LOD & - & - \\
\hline $\mathrm{Cu}$ & 324.754 & $48.88 \pm 0.08$ & 0.16 & $49.38 \pm 2.05$ & 4.15 & 0.43 \\
\hline $\mathrm{Fe}$ & 371.993 & $53.45 \pm 4.02$ & 7.52 & $54.69 \pm 1.94$ & 3.55 & 0.84 \\
\hline $\mathrm{K}$ & 766.491 & $8005.09 \pm 161.97$ & 2.02 & $8210.06 \pm 148.10$ & 1.80 & 0.93 \\
\hline $\mathrm{Mg}$ & 518.360 & $1314.24 \pm 24.65$ & 1.87 & $1336.74 \pm 61.42$ & 4.59 & 0.87 \\
\hline Mn & 403.076 & $10.01 \pm 0.02$ & 0.19 & $10.27 \pm 0.57$ & 5.55 & 0.83 \\
\hline $\mathrm{Zn}$ & 213.857 & $56.69 \pm 0.13$ & 0.23 & $55.15 \pm 3.51$ & 6.36 & 0.64 \\
\hline
\end{tabular}

${ }^{a} t$ critical $=4.30$ at $95 \%$ confidence level; $\lambda$ : wavelength; RSD: relative standard deviation; LOD: limit of detection. 
study varying from 1.80 to $6.36 \%$, indicating that the proposed procedure showed good precision.

Results obtained for the certified reference material of fish protein (DORM-4) used to confirm the accuracy of the procedure of analysis by MIP OES are presented in Table 4 . The values found in this study are close to certified values, with recoveries between 91 and 106\%. In most cases, the application of the $t$-test at a confidence interval of $95 \%$ $\left(t_{\text {critical }}=4.30\right)$ showed good agreement between the certified values, and no statistically significant difference was found, indicating that the procedure has adequate accuracy.

All values obtained for $\mathrm{Cr}, \mathrm{Fe}, \mathrm{K}, \mathrm{Mg}, \mathrm{Mn}$, and $\mathrm{Zn}$ by the addition and recovery method were also acceptable and ranged from 102.0 to $107.0 \%, 101.0$ to $102.0 \%, 99.0$ to $108.0 \%, 98.0$ to $107.0 \%, 101.0$ to $107.0 \%$, and 98.0 to $113.0 \%$, respectively.

Based on the analytical frequency, the proposed procedure using TMAH and $\mathrm{HNO}_{3}$ showed a higher analytical frequency (14 samples per $\mathrm{h}$ ) when compared to the acid digestion procedure using a microwave oven ( 9 samples per $\mathrm{h}$ ). This is due to spending less time on sample preparation in the acid proposed procedure, and also to the use of simpler instruments, allowing the use of a larger number of samples than the microwave oven in this study.

The procedure proposed in this study, allows efficient and reproducible solubilization in crustacean samples using a combination of TMAH and $\mathrm{HNO}_{3}$. This allowed to make the determinations in acidity suitable for MIP OES, since at high alkaline $\mathrm{pH}$ (greater than 9) deterioration of the quartz torch can occur. ${ }^{33}$ In addition, the procedure using TMAH and $\mathrm{HNO}_{3}$ has some advantages over conventional acid digestion procedure described by Lemos et al., ${ }^{6}$ such as less volume of reagents used and, consequently, less waste production, shorter sample preparation time, greater speed, less manipulation of the sample and possibility of using instruments simpler than a microwave oven with cavity.

\section{Determination of elements in shrimp and crab samples}

Table 5 shows the $\mathrm{Cu}, \mathrm{Fe}, \mathrm{K}, \mathrm{Mg}, \mathrm{Mn}$ and $\mathrm{Zn}$ concentrations determined in crustacean samples by MIP OES after treatment with TMAH and $\mathrm{HNO}_{3}$. The results

Table 4. Assessment of the accuracy of the procedure by certified reference material (DORM-4, fish protein) by MIP OES. Date are mean \pm standard deviation $(\mathrm{n}=3)$

\begin{tabular}{lccc}
\hline Element & Certified value $/\left(\mathrm{mg} \mathrm{kg}^{-1}\right)$ & Found value $/\left(\mathrm{mg} \mathrm{kg}^{-1}\right)$ & Recovery / \% \\
\hline $\mathrm{Cr}$ & $1.87 \pm 0.18$ & $1.99 \pm 0.01$ & 106 \\
$\mathrm{Cu}$ & $15.7 \pm 0.46$ & $15.95 \pm 0.03$ & 102 \\
$\mathrm{Fe}$ & $343 \pm 20$ & $325.72 \pm 9.35$ & 94 \\
$\mathrm{~K}$ & $15500 \pm 1000$ & $15929.02 \pm 190.14$ & 103 \\
$\mathrm{Mg}$ & $910 \pm 80$ & $833.86 \pm 0.28$ & 91 \\
$\mathrm{Mn}$ & $3.17 \pm 0.26$ & $3.33 \pm 0.23$ & 105 \\
$\mathrm{Zn}$ & $51.6 \pm 2.8$ & $52.62 \pm 1.13$ & 102 \\
\hline
\end{tabular}

Table 5. Concentration of $\mathrm{Cu}, \mathrm{Fe}, \mathrm{K}, \mathrm{Mg}, \mathrm{Mn}$ and $\mathrm{Zn}$ in crustaceans by MIP OES (mean \pm standard deviation, $\mathrm{n}=3$ )

\begin{tabular}{lccccccc}
\hline Crustacean & $\mathrm{Sample}$ & $\mathrm{Cu} /\left(\mathrm{mg} \mathrm{kg}^{-1}, \mathrm{dw}\right)$ & $\mathrm{Fe} /\left(\mathrm{mg} \mathrm{kg}^{-1}, \mathrm{dw}\right)$ & $\mathrm{K} /\left(\mathrm{mg} \mathrm{kg}^{-1}, \mathrm{dw}\right)$ & $\mathrm{Mg} /\left(\mathrm{mg} \mathrm{kg}^{-1}, \mathrm{dw}\right)$ & $\mathrm{Mn} /\left(\mathrm{mg} \mathrm{kg}^{-1}, \mathrm{dw}\right)$ & $\mathrm{Zn} /(\mathrm{mg} \mathrm{kg}$ \\
\hline \multirow{6}{*}{ Shrimp } & $\mathrm{S} 1$ & $31.47 \pm 0.73$ & $18.95 \pm 0.03$ & $12136.39 \pm 300.93$ & $1585.01 \pm 42.58$ & $3.99 \pm 0.01$ & $58.44 \pm 0.66$ \\
& $\mathrm{~S} 2$ & $45.41 \pm 2.19$ & $38.47 \pm 0.71$ & $12366.11 \pm 0.01$ & $1684.15 \pm 26.14$ & $4.00 \pm 0.01$ & $56.89 \pm 0.10$ \\
& $\mathrm{~S} 3$ & $46.30 \pm 0.68$ & $33.40 \pm 0.75$ & $12454.44 \pm 377.96$ & $1596.96 \pm 42.75$ & $5.72 \pm 0.45$ & $50.33 \pm 2.21$ \\
& $\mathrm{~S} 4$ & $49.38 \pm 2.05$ & $54.69 \pm 1.94$ & $8210.06 \pm 148.10$ & $1336.74 \pm 61.42$ & $10.27 \pm 0.57$ & $55.15 \pm 3.51$ \\
& $\mathrm{~S} 5$ & $33.84 \pm 0.02$ & $18.27 \pm 0.62$ & $12271.33 \pm 284.01$ & $1574.93 \pm 27.46$ & $3.99 \pm 0.01$ & $48.36 \pm 0.54$ \\
\hline \multirow{6}{*}{ Crab } & $\mathrm{C} 1$ & $45.69 \pm 0.03$ & $102.08 \pm 2.54$ & $15911.28 \pm 61.19$ & $3472.42 \pm 126.97$ & $2.99 \pm 0.01$ & $239.87 \pm 0.57$ \\
& $\mathrm{C} 2$ & $49.39 \pm 0.80$ & $64.73 \pm 4.28$ & $16156.38 \pm 389.85$ & $3662.73 \pm 210.07$ & $2.94 \pm 0.07$ & $235.48 \pm 2.36$ \\
& $\mathrm{C} 3$ & $61.28 \pm 0.65$ & $118.01 \pm 0.10$ & $12588.24 \pm 286.19$ & $2110.40 \pm 43.60$ & $3.08 \pm 0.14$ & $210.36 \pm 16.40$ \\
& $\mathrm{C} 4$ & $41.43 \pm 0.81$ & $118.41 \pm 2.25$ & $19327.00 \pm 136.22$ & $2363.23 \pm 48.84$ & $6.98 \pm 0.01$ & $298.26 \pm 1.04$ \\
& $\mathrm{C} 5$ & $63.80 \pm 0.04$ & $151.14 \pm 10.67$ & $17754.59 \pm 350.16$ & $2468.93 \pm 101.16$ & $11.97 \pm 0.01$ & $296.29 \pm 2.99$ \\
\multirow{2}{*}{ Mean } & $\mathrm{C} 6$ & $84.66 \pm 0.38$ & $204.15 \pm 2.27$ & $17764.67 \pm 603.17$ & $2486.93 \pm 101.16$ & $15.95 \pm 0.95$ & $294.32 \pm 0.79$ \\
& $\mathrm{~S}$ & 41.05 & 32.75 & 11487.66 & 1555.56 & 5.51 & 53.26 \\
\hline
\end{tabular}

S: shrimp samples (M. amazonicum); C: crab samples (U. cordatus); dw: dry weight. 
found for elements studied were reported in $\mathrm{mg} \mathrm{kg}^{-1}$ dry weight. The relative standard deviations (RSD) obtained in this study, which ranged from 0.01 (for $\mathrm{K}$ and $\mathrm{Mn}$ ) to 7.79 (for $\mathrm{Cu}$ ), indicate that the procedure is precise for all elements.

The most abundant elements present in crustacean samples were potassium, magnesium and zinc. Chromium presented levels below the limit of detection in crustacean samples, i.e., less than $0.12 \mathrm{mg} \mathrm{kg}^{-1}$. Literature reports studies with higher $\mathrm{Cr}$ levels in shrimp and crab species from other locations. Some authors reported $\mathrm{Cr}$ concentrations in shrimp species in Brazil and Malaysia ranging from 0.13 to $1.05 \mu \mathrm{g} \mathrm{g}^{-1}$ and from 2.5 to $10.1 \mathrm{mg} \mathrm{kg}^{-1}$, respectively. ${ }^{34,35}$ Another study ${ }^{36}$ with two shrimp species consumed in the state of Bahia (Farfantepenaeus paulensis and Xiphopenaeus kroyeri), reported $\mathrm{Cr}$ levels ranging from 8.0 to $17.84 \mu \mathrm{g} \mathrm{g}^{-1}$. The average $\mathrm{Cr}$ content in a red crab species in Mexico was $88.69 \mathrm{mg} \mathrm{kg}^{-1}$ (male crabs). ${ }^{37}$ Higher $\mathrm{Cr}$ levels in other species are probably due to the bioaccumulation of this metal in aquatic organisms, highlighting the importance of determining this constituent also as an indicator of environmental contamination.

Average $\mathrm{Cu}$ concentrations in crustaceans were $41.05 \mathrm{mg} \mathrm{kg}^{-1}$ for shrimp and $57.70 \mathrm{mg} \mathrm{kg}^{-1}$ for crab. These values are close to those found by Anandkumar et al., ${ }^{35}$ who obtained average $\mathrm{Cu}$ concentration of $54.98 \mu \mathrm{g} \mathrm{g}^{-1}$ in five shrimp species and by Nascimento et al. ${ }^{34}$ whose $\mathrm{Cu}$ values obtained from shrimp samples ranged from 7.1 to $47.9 \mu \mathrm{g} \mathrm{g}^{-1}$. On the other hand, Annabi et al..$^{38}$ found average $\mathrm{Cu}$ content of $206.45 \mu \mathrm{g} \mathrm{g}^{-1}$ in blue crab (Portunus segnis) samples in Tunisia, higher than the average value found in this study.

Iron concentrations in crustaceans ranged from 18.27 to $54.69 \mathrm{mg} \mathrm{kg}^{-1}$ in shrimp and from 64.73 to $204.15 \mathrm{mg} \mathrm{kg}^{-1}$ in crab. These values are above levels obtained by Baki et al. ${ }^{39}$ who reported average Fe content of $18.71 \mathrm{mg} \mathrm{kg}^{-1}$ for shrimp and from 29.56 to $168.82 \mathrm{mg} \mathrm{kg}^{-1}$ for crab. In other study, ${ }^{36}$ it was found average Fe content of $85.05 \mathrm{mg} \mathrm{kg}^{-1}$ for crab muscle, lower than that obtained in this study.

Potassium was the element that presented the highest concentrations in crustacean species under study, with average contents of $11487 \mathrm{mg} \mathrm{kg}^{-1}$ for shrimp and $16583 \mathrm{mg} \mathrm{kg}^{-1}$ for crab. Similar results were obtained by other authors ${ }^{40}$ who reported average $\mathrm{K}$ concentrations in seafood of $5770 \mathrm{mg} \mathrm{kg}^{-1}$.

The average magnesium contents obtained in this study were $1555 \mathrm{mg} \mathrm{kg}^{-1}$ for shrimp and $2760 \mathrm{mg} \mathrm{kg}^{-1}$ for crab. Other authors ${ }^{41}$ obtained $\mathrm{Mg}$ values close to those obtained in this study, with average concentrations from 1630 to $1830 \mathrm{mg} \mathrm{kg}^{-1}$ in seafood in Italy.

Zinc contents in samples ranged from 48.36 to $58.44 \mathrm{mg} \mathrm{kg}^{-1}$ (mean concentration of $53.26 \mathrm{mg} \mathrm{kg}^{-1}$ ) for shrimp and from 210.36 to $298.26 \mathrm{mg} \mathrm{kg}^{-1}$ (mean concentration of $262.43 \mathrm{mg} \mathrm{kg}^{-1}$ ) for crab. These results are in accordance with levels reported in literature. Migues et al. ${ }^{36}$ reported average $\mathrm{Zn}$ concentrations in different shrimp species in Brazil ranging from 36.6 to $44.3 \mathrm{mg} \mathrm{kg}^{-1}$. Luo et al. ${ }^{42}$ obtained $\mathrm{Zn}$ contents ranging from 63.1 to $97.9 \mathrm{mg} \mathrm{kg}^{-1}$ in crabs from various locations in China. In a study on crab species carried out in Mexico, Perry $\mathrm{et} \mathrm{al.}{ }^{37}$ reported average $\mathrm{Zn}$ values ranging from 206 to $326 \mathrm{mg} \mathrm{kg}^{-1}$.

\section{Conclusions}

The proposed procedure using TMAH and $\mathrm{HNO}_{3}$ in the preparation of crustacean samples provided quicker and less manipulated samples, reducing the consumption of reagents when compared to most acid digestion procedures, generating smaller amounts of residue and ensuring accurate results. In addition, this procedure allowed the elemental determination in an adequate acidity for the MIP OES. In this study, MIP OES proved to be an adequate technique for $\mathrm{Cr}, \mathrm{Cu}, \mathrm{Fe}, \mathrm{K}, \mathrm{Mg}, \mathrm{Mn}$, and $\mathrm{Zn}$ determination, combining practicality and low cost in routine analysis.

\section{Acknowledgments}

The authors are grateful to Coordenação de Aperfeiçoamento de Pessoal de Nível Superior (CAPES) for research funding and fellowships.

\section{References}

1. Noël, L.; Chafey, C.; Testu, C.; Pint, J.; Velge, P.; Guérin, T.; J. Food Compos. Anal. 2011, 24, 368.

2. Souza, M. M. M.; Furtunato, D. M. N.; Cardoso, R. C. V.; Argôlo, S. V.; Silva, I. R. C.; Santos, F. P.; Bol. Inst. Pesca 2013, $39,359$.

3. Innis, S. M.; J. Nutr. 2007, 137, 855.

4. Sirot, V.; Dumas, C.; Leblanc, J.; Margaritis, I.; Br. J. Nutr. 2007, 105, 1369.

5. Medeiros, R.; dos Santos, L. M. G.; Freire, A. S.; Santelli, R. E.; Braga, A. M. C. B.; Krauss, T. M.; Jacob, S.; Food Control 2012, 23, 535.

6. Lemos, M. S.; Cruz, A. S.; Fernandes Dantas, K. G.; Biol. Trace Elem. Res. 2019, 191, 224.

7. Citak, D.; Silici, S.; Tuzen, M.; Soylak, M.; J. Food Sci. Technol. 2012, 47, 107.

8. Nunes, A. M.; Sousa, R. A.; Silva, C. S.; Peixoto, R. R. A.; Vieira, M. A.; Ribeiro, A. S.; Cadore, S.; J. Food Compos. Anal. 2013, 32, 1.

9. Soares, A. R.; Nascentes, C. C.; Talanta 2013, 105, 272. 
10. Ghisi, M.; Chaves, E. S.; Quadros, D. P. C.; Marques, E. P.; Curtius, A. J.; Marques, A. L. B.; Microchem. J. 2011, 98, 62.

11. Torres, D. P.; Martins-Teixeira, M. B.; Cadore, S.; Queiroz, H. M.; Anal. Methods 2016, 8, 4263.

12. Nóbrega, J. A.; Santos, M. C.; Sousa, R. A.; Cadore, S.; Barnes, R.; Trato, M.; Spectrochim. Acta, Part B 2006, 61, 465.

13. Silva, D. S.; dos Santos, C. S.; Pando, L. A.; Gomes, M. S.; Novaes, C. G.; dos Santos, W. N. L.; Bezerra, M. A.; Food Chem. 2019, 273, 71.

14. Sousa, R. A.; Sabarense, C. M.; Prado, G. L. P.; Metze, K.; Cadore, S.; Talanta 2013, 104, 90.

15. Aranha, T. S. C. P.; Oliveira, A.; Queiroz, H. M.; Cadore, S.; Food Control 2016, 57, 447.

16. Tavares, K. N.; Lucena, I. O.; Toaldo, I. M.; Haas, I. C. S.; Luna, A. S.; Gois, J. S.; Anal. Lett. 2020, 53, 2252.

17. Savio, M.; Ortiz, M. S.; Almeida, C. A.; Olsina, R. A.; Martinez, L. D.; Gil, R. A.; Food Chem. 2014, 159, 433.

18. Oliveira, A. F.; Gonzalez, M. H.; Nogueira, A. R.; Microchem. J. 2008, 143, 236.

19. Goncalves, D. A.; Amais, R. S.; Fontoura, B. M.; Jones, B. T.; Nóbrega, J. A.; Donati, G. L.; J. Anal. At. Spectrom. 2016, 31 , 1097.

20. Carvalho, L. S. B.; Silva, C. S.; Nóbrega, J. A.; Boa Morte, E. S.; Santos, D. C. M. B.; Korn, M. G. A.; J. Food Compos. Anal. 2020, 86, 103376.

21. Virgilio, A.; Gonçalves, D. A.; Mcsweeney, T.; Neto, J. A. G.; Nóbrega, J. A.; Donati, G. L.; Anal. Chim. Acta 2017, 982, 31.

22. Karlsson, S.; Sjöberg, V.; Ogar, A.; Talanta 2015, 135, 124.

23. Li, W.; Simmons, P.; Shrader, D.; Herrman, T. J.; Day, S. Y.; Talanta 2013, 112, 43.

24. Amais, R. S.; Donati, G. L.; Nóbrega, J. A.; Microchem. J. 2013, 106, 318.

25. Silva, S. A.; Bonemann, D. H.; da Silva, J. S.; Timm, J. G.; Ribeiro, A. S.; Vieira, M. A.; Braz. J. Food Technol. 2019, 22, 1.

26. Ozbek, N.; Akman, S.; Food Chem. 2016, 192, 295.

27. Szymczycha-Madeja, A.; Arabian J. Chem. 2017, 10, 3913.
28. Jankowski, K. J.; Reszke, E.; Microwave Induced Plasma Analytical Spectrometry, $1^{\text {st }}$ ed.; Royal Society of Chemistry: Cambridge, United Kingdom, 2010.

29. Thomsen, V.; Roberts, G.; Burguess, K.; Spectroscopy 2000, 15,33 .

30. Williams, C. B.; Amais, R. S.; Fontoura, B. M.; Jones, B. T.; Nóbrega, J. A.; Donati, G. L.; TrAC, Trends Anal. Chem. 2019, 116, 151.

31. Ribeiro, A. S.; Moretto, A. L.; Arruda, M. A. Z.; Cadore, S.; Microchim. Acta 2003, 141, 149.

32. Matusiewicz, H.; Golik, B.; Microchem. J. 2004, 76, 23.

33. Oliveira, A. A.; Nóbrega, J. A.; Pereira-Filho, E. R.; Quim. Nova 2012, 35, 1299.

34. Nascimento, J. R.; Sabadini-Santos, E.; Carvalho, C.; Keunecke, K. A.; César, R.; Bidone, E. D.; Mar. Pollut. Bull. 2017, 114, 1007.

35. Anandkumar, A.; Nagarajan, R.; Prabakaram, K.; Rajaram, R.; Reg. Stud. Mar. Sci. 2017, 16, 79.

36. Migues, V. H.; Bezerra, M. A.; de Francisco, A. K.; Guerrazzi, M. C.; Affonso, P. R. A. M.; Bull. Environ. Contam. Toxicol. 2013, 91, 292.

37. Perry, H.; Isphording, W.; Trigg, C.; Riedel, R.; Mar. Pollut. Bull. 2015, 101, 845.

38. Annabi, A.; Bardellib, R.; Vizzinic, S.; Mancinelli, G.; Mar. Pollut. Bull. 2018, 136, 454.

39. Baki, M. A.; Hossain, M. M.; Akter, J. A.; Quraishi, S. B.; Shojib, M. F. H.; Ullah, A. K. M. A.; Khan, M. F.; Ecotoxicol. Environ. Saf. 2018, 159, 153.

40. Lu, G. Y.; Wang, W. X.; Sci. Total Environ. 2018, 626, 307.

41. Mancinelli, G.; Papadia, P.; Ludovisi, A.; Migoni, D.; Bardelli, R.; Fanizzi, F. P.; Vizzini, S.; Sci. Total Environ. 2018, 624, 1455.

42. Luo, R.; Jiang, T.; Chen, X.; Zheng, C.; Liu, H.; Yang, J.; Food Chem. 2019, 274, 1.

Submitted: February 26, 2020 Published online: October 6, 2020 